\title{
TEXTO TRÁGICO, IMAGEM CÊNICA, MÚSICA DITIRÂMBICA: UMA PROPOSTA PARA A LEITURA DA TRAGÉDIA ATENIENSE
}

\author{
TRAGIC TEXT, SCENIC IMAGE, DITHYRAMBIC MUSIC: \\ A PROPOSITION FOR READING THE ATHENIAN TRAGEDY
}

\author{
Enéias Farias Tavares \\ Universidade Federal de Santa Maria, Santa Maria, RS, Brasil
}

Ilustrações de Leonardo Kozen ${ }^{1}$

\begin{abstract}
Resumo: Neste ensaio, descreverei a dionisíaca ateniense em relação ao festival trágico que nela inseria-se como central. Nessa discussão, a arquitetura do teatro de Dionísio e a utilização de adereços como máscaras, além da presença do maquinário cênico, evidenciará a complexidade desse fenômeno. Na parte final, refletirei, a partir de autores como Nieztsche, Snell e outros, sobre a necessidade de se reinterpretar a tragédia a partir dos elementos cênicos, elementos que lançam raios de luz sob os obscuros pontos resultantes da centralidade do texto na interpretação da tragédia. Nesse sentido, o que pretendo é evidenciar a importância da imagem corporal dos atores e dos integrantes do coro, do som de suas vozes individuais ou coletivas e do movimento de sua dança para a compreensão da arte dramática de Ésquilo, Sófocles e Eurípides.
\end{abstract}

Palavras-Chave: Tragédia Grega, Artes da Cena, Crítica Literária.

Abstract: In this essay, I will describe the Athenian Dionysian in relation to the tragic festival that was central to its creation. In this discussion, the architecture of the Dionysus Theater and the use of scenic adornments such as masks and adornments, besides the presence of the scenic machinery, will reveal the complexity of this phenomenon. In the final part of this text, I will reflect, from authors like Nieztsche, Snell and others, about the importance of reinterpreting the textual tragedy from its scenic elements, elements that cast rays of light on the shady spots created by centrality of the text in the interpretation of tragedy. In this sense, what I would like to demonstrate is the importance of the body image of actors and choir members, the sound of their individual or collective voices and the movement of his dancing to understanding the Aeschylus, Sophocles and Euripides' drama.

Keywords: Greek Tragedy, Scenic Arts, Literary Criticism.

\section{O Ressurgimento da Tragédia como Espetáculo Cênico}

No Ocidente, a tragédia ateniense passou por um longo processo de leitura, tradução e recepção textual que deslocou o aspecto discursivo da sua utilização cênica. Nesse âmbito, analisou-se o texto trágico mais em função da sua construção textual do que em virtude de seu contexto social específico -

\footnotetext{
${ }^{1}$ Formou-se em Artes Visuais pela Universidade Federal de Santa Maria em 2013, atua na área de desenho, pintura e ilustração. Sua temática nas produções artísticas envolve a fusão de elementos opostos: o real e o imaginário, busca através desta mistura por maneiras de despeitar questionamentos ou reflexões quanto a complexidade daquilo que julgamos e percebemos.
} 
componente de uma festa religiosa anual - ou da sua constituição múltipla misto de diálogo dramático, canto e música coral, encenação e dança.

Esse descolamento do aspecto textual das práticas cênicas e corporais da tragédia resultou na abstração das figuras heroicas e na elevada valorização de determinados conceitos associados ao drama grego, como "purificação", terror, piedade, "desmedida", "falta trágica", "imitação", "enredo" e "peripécia" (respectivamente, kátharsis, phóbos, éleos, hybris, hamartia, mimeses, mythos e peripateia). Desse modo, foram justamente tais termos que se tornaram pedra de toque para a compreensão do trágico. Esse esforço de abstração conceitual não é tardio, tendo nascido pouco depois do desaparecimento da tragédia clássica no final do século $\mathrm{V}$ a.C., com o primeiro autor a pensar o gênero em termos teórico-estruturais.

$\mathrm{Na}$ Poética, Aristóteles dissociou o texto da encenação ao privilegiar uma determinada experiência com o enredo trágico, que resultaria na catarse dos sentimentos de temor e piedade produzidos no decorrer do drama. Logicamente, trata-se de um estudo poético, não teatral/cênico, o que justifica, até certo ponto, a afirmação de que se poderia chegar à experiência purificadora e curativa da "catarse" apenas na leitura, não diante da encenação trágica. Todavia, o que não passou de um comentário lógico por parte de um estudioso da poesia, ganhou estatuto de lei por parte daqueles que valorizavam o texto em detrimento da encenação (Malhadas, 2003, p. 49).

Passados dois milênios, foi Nietzsche, no polêmico O Nascimento da Tragédia (1872) que atentou para a importância do som musical e da imagem corporal, ou seja, da própria encenação e não apenas do "libreto" que chegou até a modernidade. Em "O Drama Musical Grego" (1870), destacou os efeitos estéticos e filosóficos próprios ao drama no contexto grego. No século vinte, não apenas os estudos históricos como também antropológicos - cujas origens remontam aos contemporâneos alemães de Nietzsche, entre eles um de seus principais críticos, Wilamowitz-Moellendorff - acrescentaram uma rica e fértil paleta de cores às pálidas projeções modernas direcionadas ao contexto ateniense do Séc. V. Como o próprio Nietzsche destaca, ainda em sua conferência de 1870, era necessário cuidado para não "super-helenizarmos" o "helênico", para não interpretarmos como "incolores" ou desbotados os coloridos e decorados mármores do seu estatuário (2005, p. 50-51).

Nesse aspecto, a compreensão do trágico foi enriquecida, no século $\mathrm{XX}$, pelo suporte histórico, arqueológico e antropológico. Elementos antes obscuros nos textos dramáticos atenienses passaram a ser vistos com maior apuro, entre eles, a criação dos dramas exclusivamente para a apresentação cênica das dionisíacas anuais; as camadas de referências políticas, religiosas e filosóficas, entre outras, que se sobrepõem à camada principal do enredo mítico; a relação entre a música trágica e a tradição lírica e entre a personagem dramática e a execução do aedo épico; a proximidade do culto dionisíaco com 
outros rituais religiosos, em sua grande maioria dedicados aos deuses olímpicos; e por fim, a dionisíaca anual como espaço público de apresentação, recepção e discussão de temas míticos em relação a temas contemporâneos.

Neste ensaio, detalharei a estrutura da dionisíaca anual em relação ao festival trágico que nela inseria-se como elemento central. Nessa discussão, a arquitetura do teatro de Dionísio e a utilização de adereços como máscaras, além da presença do maquinário cênico, evidenciará a complexidade desse fenômeno e os esforços nele investidos. Na parte final, refletirei, a partir de autores como Nieztsche, Snell e outros, sobre a necessidade de se reinterpretar a tragédia a partir dos elementos cênicos, elementos que lançam raios de luz sob os obscuros pontos resultantes da centralidade do texto na cultura ocidental. Nesse sentido, pretendo destacar a importância da imagem corporal dos atores e dos integrantes do coro, do som de suas vozes individuais ou coletivas e do movimento de sua dança para a compreensão da arte dramática de Ésquilo, Sófocles e Eurípides, num esforço de ler de modo diverso o texto trágico, dando voz a elementos que a cultura ocidental silenciou.

\section{As Dionisíacas Atenienses e a Origem do Teatro Ateniense}

O criador do drama grego teria sido Téspis, poeta popular de Metimna de Lesbos que vivera entre o fim do século sexto e início do quinto a.C.. Compatriota de Arion - outro poeta que a tradição relaciona com o surgimento de ritos dramáticos - Téspis foi o vencedor do primeiro festival trágico ateniense (Grimal, 1986, p. 31), sendo também referido como aquele que transformara músicas entoadas pelo coro em homenagem a Dionísio em diálogos dramáticos, tornando-se, assim, para alguns autores, o próprio criador do jogo dramático (Lesky, 2007, p. 15). Embora haja registro de produções trágicas anteriores, a data comumente aceita para a criação da tragédia clássica é 534 a.C., quando o tirano Pisístrato instituiu as dionisíacas urbanas.

Segundo Romilly, o próprio Pisístrato é, "em certo sentido, Dioniso o tirano ateniense havia desenvolvido o culto a essa divindade. Ele ergueu, aos pés da Acrópole, um templo a Dioniso de Eleutério, e instituiu em sua honra as festas dionisíacas urbanas, que seriam aquelas da tragédia” (1998, p. 16). Tal importância dada à figura do tirano é, no mínimo, curiosa, uma vez que seria o próprio gênero trágico, décadas depois, que condenaria o regime tirânico e suas comuns desmedidas - vide, sobretudo, as peças de Sófocles.

Albin Lesky destaca a importância de Pisístrato para a criação e o desenvolvimento do drama como o conhecemos. Segundo o crítico, teria sido obra deste tirano o próprio aperfeiçoamento

da festa dentro do culto do Estado. Essa festa do mês primaveril de Elafebolion não era dedicada ao Dioniso panjônico adorado nas Lenéias e nas Atestérias. $\mathrm{O}$ deus dessa festa é o Dioniso Eleutério, levado a Atenas da cidade de Eleuteras, 
na fronteira ático-beócia. A Comédia pertence ao Dioniso das Lenéias, e a Tragédia ao Dioniso Eleutério das dionisíacas urbanas. Nessa festa, sob Pisístrato, num dos três primeiros anos da Olimpíada de 536 ou 532, foi representada pela primeira vez uma tragédia de Téspis. A partir dessa época, fixase a ligação entre o drama trágico e as dionisíacas urbanas, e posteriormente assume a forma de um festival de três dias para a apresentação de uma tetralogia, três tragédias e um drama satírico. Em 486, a comédia se havia introduzido nas dionisíacas urbanas. (2010, p. 76)

A Dionisíaca Urbana era um grande evento anual de cinco dias, preparado com mais de 10 meses de antecedência. Festejava-se Dionísio em períodos primaveris e em festas de casamento. Um dos principais elementos do culto era o sacrifício animal, a música e a dança que acompanhava o sacrifício. Além desses, a utilização de máscaras pelo sacerdote e pelos dançarinos também migraria para a criação cênica, porém com propósitos e utilizações diversas (Gassner, 2007, p. 13). Compreender a multiplicidade da religião dionisíaca é também compreender a riqueza do seu festival., cuja origem remonta às festividades rurais em homenagem e esse deus ctônico.

Filho de Zeus e da princesa tebana Sêmele, Dionísio simbolizava elementos diversos na cultura grega. Easterling afirma que ele era comumente figurado como (I) deus do cultivo da uva e da produção de vinho; (II) deus da natureza selvagem, o que inclui a dimensão da fertilidade e da sexualidade; (III) deus da possessão extática, presente, sobretudo, no êxtase das mênades ou bacantes; (IV) deus da dança, acompanhado de sátiros e das suas supracitadas adoradoras; (V) deus da máscara e do disfarce; aquela presente no ritual e no drama e este ilustrado no enredo de As Bacantes, de Eurípides, no qual Dionísio chega a Tebas disfarçado de mortal; e, por fim, (VI) deus da iniciação mística e dos mistérios além vida (1997, p. 45). Ainda acrescenta-se, na interpretação de Detienne, um sétimo caráter à identidade de Dionísio: deus do gênio estrangeiro ou estranho, cuja presença da máscara, seja a do próprio deus ou a de qualquer outra divindade ou herói, garantia sua alteridade (1988, P. 22).

No primeiro dia do festival urbano, procissões marcavam o caráter sacro do festejo. Os três dias seguintes eram dedicados às tragédias - que eram finalizadas por um drama satírico - e o último, às comédias (Finley, 1988, p. 87). Cada autor trágico inscrevia uma trilogia de tragédias. Em Ésquilo, a trilogia desenvolvia um tema e um enredo único, como é o caso da Orestia composta de Agamêmnon, Coéforas e Eumênides - e da Tebaida - que incluía Laios, Édipo e Sete contra Tebas, sendo que destas apenas a última peça sobreviveu. Em Sófocles e Eurípides, a trilogia não apresentava enredo de desenvolvimento único, e sim uma relação temática que perpassava os três dramas, interdependentes em seu enredo (Thiercy, 2009, p. 13).

Depois de o texto ser composto por um poeta, a montagem ficava aos cuidados de um coreuta, responsável tanto pelo financiamento da peça quanto pela direção, ensaio e pagamento dos atores e dos integrantes do coro. 
Este era composto de doze ou quinze cantores/bailarinos, cidadãos que por sorteio eram escolhidos para integrarem o espetáculo. O mesmo não acontecia com os papeis principais, encenados por atores profissionais. As dionisíacas premiavam os melhores poetas, coreutas, integrantes do coro e atores, resultando num evento não só religioso como também cultural, onde a disputa entre os melhores artistas demandava rigorosa preparação (Finley, 1988, p. 88).

A estrutura do drama grego era concebida de forma orgânica, em uma progressão que indicava a entrada e a saída dos atores e do coro. Aristóteles, na seção doze da Poética, registrou a organização desse drama. A peça iniciava com um Prólogo, no qual os atores apresentavam o assunto da peça. A seguir, entrava o coro, para a primeira execução de canto, música e dança, chamada Párodo, quase sempre de conteúdo sacro, em homenagem a um ou mais deuses. Esse início duplo era seguido de Episódios Dramáticos, nos quais se desenrolava a peça. Cada Episódio dramático era entrecortado por um Estásimo, ode coral que ora comentava a ação dos episódios ora suplicava aos deuses pela resolução do conflito. Nessa progressão, o número de episódios correspondia ao mesmo número de estásimos, embora pudesse variar de autor para autor e de peça para peça. Édipo Rei, de Sófocles, por exemplo, tem três episódios e três estásimos. Agamêmnon, de Ésquilo, quatro. Medeia, de Eurípides, cinco, e As Bacantes, quatro. A peça findava no Exodo, cena final que encerra a tragédia após o último estásimo (Romilly, 1998, p. 25).

Como se pode notar, tratava-se de um fenômeno cultural, de periodicidade anual, que recebia a atenção de toda a comunidade. Com meses de antecedência, figuras públicas, religiosas ou políticas, atores profissionais e cidadãos que constituiriam o coro e o público, aguardavam o início dos trabalhos em homenagem ao deus do vinho, da uva, da fertilidade e da morte. Foi esse cenário que deu origem aos três grandes dramaturgos do quinto século e ao gradativo aperfeiçoamento do teatro grego como o conhecemos.

\section{III. Ésquilo, Sófocles e Eurípides: A dimensão polifônica da tragédia}

Dos diversos autores trágicos do século $\mathrm{V}$ a.C., o tempo nos legou as obras de três. Ésquilo (525-456 a.C), autor de Os Persas, Prometeu Acorrentado e Oréstia, entre outras, é pensado pela crítica como o tragediógrafo que evidencia os efeitos positivos da vitória grega contra os persas em Maratona (490 a.C.) e Salamina (480 a.C.). Em suas peças - mais de oitenta, das quais sobreviveram sete - a confiança nos deuses é evidente, sendo esses responsáveis não apenas pela punição da hybris humana - como em Os Persas - como pela constituição de algumas instituições atenienses - como a metafórica substituição da lei primitiva pelo moderno sistema jurídico na Oréstia (Gassner, 2007).

Eurípides (480-406 a.C.) é o autor mais preservado - das suas oitenta tragédias, dezessete sobreviveram -, fruto da sua popularidade posterior no 
mundo alexandrino e romano. Nele, evidencia-se uma desconfiança para com a religião tradicional, resultado da filosofia sofista que seria imperfeitamente relacionada a Sócrates por comediógrafos como Aristófanes. Em sua tragédia, os deuses são apresentados como vingativos passionais e humanos, em paixões motivadas por inveja e ciúme, como é o caso da participação de Afrodite e Dionísio em Hipólito e As Bacantes. Em Medeia, esses são apenas referidos, não interferindo na trama central, que resulta apenas da ação humana (Thiercy, 2009 , p. 22). Em contraste com Ésquilo, é o homem e seus novos problemas filosóficos, morais e também existenciais que vem à tona em de Eurípides, o menos popular entre seus contemporâneos (Snell, 2009, p. 113-114).

Entre esses dois extremos, que correspondem ao início e ao fim da tragédia do século $\mathrm{V}$ - em autores que foram respectivamente testemunhas das Guerras Pérsicas e da Guerra do Peloponeso -, está Sófocles (497-406 a.C.). De cento e vinte dramas, restaram sete, estando entre eles a trilogia tebana Édipo Rei, Édipo em Colono e Antígona, série de tragédias dedicada ao drama dos labdácidas, encenadas em diferentes momentos. Sófocles, contemporâneo de Eurípides, e também testemunha de uma guerra que em quase trinta anos esgotaria atenienses e espartanos, apresenta uma visão mais próxima da religiosidade de Ésquilo. Todavia, uma religiosidade que indicia sinais de desgaste institucional e espiritual. Por outro lado, é o ideal do homem grego que surge em seus dramas. Neles, o herói trágico surge como ser integral e determinado, mesmo em sua derrocada, reunindo qualidades comumente relacionadas ao próprio ideal ateniense do seu tempo (Jaeger, 2001).

Nas suas tragédias, os três poetas encenaram não apenas uma instigante reinterpretação dos mitos antigos, bebendo da fonte da poesia épica de Homero e outros, como também promoveram uma investigação da sua própria sociedade. Assim, se o enredo da tragédia buscou no passado épico seus principais temas e personagens, o texto usado pelos poetas trágicos objetivou refletir sobre diversos problemas e matizes contemporâneos. Nesse sentido, a tragédia grega apresentava em sua construção, no mínimo três eixos temáticos e caracteriológicos, a saber, o mítico, o religioso e o político.

$\mathrm{Na}$ Ilíada homérica, três heróis prenunciam a desmedida e a derrocada trágica: Pátroclo, Heitor e Aquiles. Esses tornam-se, para os gregos, modelos bélicos e existenciais. Se para os deuses, a guerra não passa de um interessante espetáculo, às vezes resultando do próprio capricho divino, para os guerreiros gregos ela é a concretização da aretê (virtude), um conjunto de valores que garantirão sua kleos (glória) e que serão preservados e divulgados após sua morte. Conforme Lesky afirma, essa "luta dos deuses entre si não passa de briga caprichosa, autêntica brincadeira, da qual o hílare pai dos deuses desfruta. Os homens, porém, neste campo de batalha, arriscam tudo o que têm e tudo o que perderão para sempre na morte amarga" (2010, p. 24). 
Além de Homero e do ciclo troiano, os trágicos buscam outros temas míticos para a sua criação: a guerra entre deuses titânicos e olímpicos presente no Prometeu de Ésquilo; as histórias que rememoram os feitos de Hércules - como o Hércules Furioso de Eurípides; os mitos relacionados à cidade de Atenas - em especial o Hipólito do mesmo autor; os rituais em homenagem a Dionísio - base para a última peça de Eurípides, As Bacantes; as aventuras de Jasão e os Argonautas - que culminarão em Medeia. Entretanto, nenhum tema seria tão central à criação grega quanto a série de maldições familiares que envolvem a casa dos labdácidas - mito tão antigo quanto o ciclo troiano e que inspirará Sete contra Tebas de Ésquilo, Antígona e Édipo Rei de Sófocles, além de As Fenícias de Eurípides (Burian, 1997).

Sobre o eixo religioso, a tragédia nasce do sacrifício de um animal, um bode, ao deus do êxtase, do vinho, do descontrole e das paixões, Dionísio, filho de Zeus com uma tebana, o que o aproxima dos mitos desta cidade (Graff, 2007). Na quarta seção da Poética, Aristóteles diz que a tragédia nasceu dos ditirambos - cantos rituais com o acompanhamento da flauta dupla, Aulos - em homenagem a Dionísio e a Comédia de Cantos Fálicos - associados aos populares ritos de fertilidade, plantio e colheita (Easterling, 1997, p. 39).

Essas correlações são válidas pelo fato dessas origens - populares e religiosas - marcarem etimologicamente os dois grandes gêneros dramáticos, significando tragédia o "Canto do Bode" e comédia o "Canto de Alegria." Sobre o significado desse "Canto do Bode", há no mínimo três possibilidades para seu significado. Primeiro, referencia o grito do animal sacrificado a Dionísio. Segundo, alude ao canto dos adoradores de Dionísio, que se vestiam de Sátiros e que dançavam ao redor do sacerdote, dando origem à forma circular do ritual e depois do teatro. Os Sátiros são chamados de Bodes no fragmento do Prometeu Pirceu de Ésquilo. Por fim, o canto pelo bode em referência ao prêmio nos festivais dramáticos (Lesky, 2010, p. 71). Embora não exista consenso, há de forma clara uma relação entre o animal característico do ritual dionisíaco e o gênero dramático que homenageia essa divindade.

Entretanto, se por um lado a tragédia homenageia Dionísio, por outro, ela "Não tem a ver com Dionísio". Na sua construção, são mais comuns as menções ou mesmo a presença de outros deuses olímpicos, como Zeus, Atena, Afrodite, Ártemis e Apolo, do que ao filho de Zeus e Sêmele. A partir dos dois filhos de Zeus, costumou-se associar a tragédia como uma aproximação entre o noturno deus do vinho e o diurno deus das artes, hipótese que embasa o argumento de Nietzsche em O Nascimento da Tragédia.

Essa aparente ausência de Dionísio, todavia, é relativizada quando se pensa em outros símbolos que se multiplicam no decorrer de várias peças. Como Dionísio é comumente relacionado com a revolta à autoridade constituída, Prometeu Acorrentado é naturalmente báquica. Como o filho de Sêmele tem relação com Hades, as fúrias da Oréstia mantém correlação a ele. 
Como Édipo e sua família descendem de Cadmo, pai de Sêmele, os dramas dedicados ao labdácidas têm relação direta com Dionísio, sendo As Bacantes o exemplo mais evidente. Se levarmos em conta que Dionísio Eleutério significa "libertador" e que na abertura das Dionisíacas prisioneiros eram libertados, tal ausência/presença do deus é melhor compreendida (Malhadas, 2003, p. 83).

Além disso, pensa-se que Dionísio apareça tão pouco porque sempre estava em cena, simbolizado pela presença de seu sacerdote ou por sua estátua, que era levada do templo de Eleusis - região limítrofe entre a Ática e a cidade de Tebas - ao teatro que leva seu nome, num cortejo que dava abertura aos trabalhos das dionisíacas (Rhem, 2007, p. 184). As Bacantes, coda e epitáfio da produção trágica, consegue conjugar na sua oposição Dionísio/Penteu todos esses elementos. $\mathrm{O}$ fato de ter sido composta na Macedônia apenas fortalece e evidencia as razões da sua marcante ausência no drama ateniense.

Além das dimensões mítica e religiosa, o drama discutia questões políticas, sociais, jurídicas e morais que diziam respeito aos problemas da polis e de seus cidadãos (Hesk, 2007). Há, ao menos, três exemplos de tragédias baseadas em temas históricas. A Tomada de Mileto (492 a.C.) revive a revolta da cidade jônica contra os Persas. Em 472, As Fenícias de Frínico recupera em um dos estásimos a derrocada de Xerxes em Salamina (Thiercy, 2009, p. 13). Inegavelmente, é a vitória grega contra os Persas a responsável pelo revigorado heroísmo grego no século $\mathrm{V}$, heroísmo que marcaria uma cidade como Atenas, tão decidida a repensar sua política, suas leis e sua filosofia.

Nenhum dramaturgo exemplifica tanto esse ideal quanto Ésquilo. Os Persas (472) dramatiza a vitória contra a opressão inimiga; sua trilogia Oréstia (458) recria a substituição de uma primitiva de justiça, baseada na vingança, pelo secular sistema jurídico ateniense; Édipo Rei (430) e Antígona (442) tratam do papel do tirano ou do homem sob cujos ombros repousa a ordem estatal. Eurípides afasta-se do tema político, o que pode explicar suas poucas vitórias nos festivais e a futura crítica que Aristófanes faria a ele em As rãs (404). Tal dimensão política é perceptível em todo o drama do século $\mathrm{V}$, o que reforça a leitura do gênero como mais amplo do que simplesmente religioso, artístico ou mítico. Nele, Atenas revisa sua própria estrutura social (Gassner, 2007, p. 15).

Como visto, a tragédia ateniense apresentava uma série de níveis temáticos que tornava sua encenação um conjunto múltiplo de temas, tópicos, estilos e reflexões. François Ost, refletindo sobre essa multiplicidade temática, chama o gênero de "construção polifônica" (2004, p. 110). Em outros termos, o ateniense que constituía o público da tragédia grega acessava na sua apresentação os mitos do passado, os ritos religiosos do presente e os temas que constituíam os debates sociais e políticos sobre o futuro da polis. Tal polivalência temática e estilística, que notamos no texto de autores como Ésquilo, Sófocles e Eurípides, tem a sua popularidade explicada na observação 
de seu contexto de produção. Na próxima seção deste texto, refletiremos sobre a encenação dos dramas trágicos do século quinto no seu próprio contexto.

\section{A encenação trágica: imagem cênica e música ditirâmbica}

Diferente de poesia escrita para indivíduos - ideia impensável pelo menos até o primeiro século a.C. no contexto alexandrino e latino - a tragédia ateniense objetiva uma audiência coletiva. Seu apelo estava justamente em ser composta para um evento anual e único, o que garantia sua importância e seu inegável verniz ritualístico e religioso, além de seu caráter mítico, artístico e também político. Diferente da textualidade do libreto que a posteridade nos legou, o público ateniense acessava uma série de elementos cênicos que apresentavam imagem e som, dramatização e música, diálogo e dança.

Nesse sentido, seria premente compreender as não apenas múltiplas camadas do estrato histórico, camadas que auxiliam na leitura e na tradução do gênero trágico às audiências contemporâneas. Em adição, deve-se igualmente buscar - com a mesma energia que se penetra no nível da linguagem e do dado contextual - uma compreensão dos elementos cênicos e musicais que compunham o drama ateniense. Tal entendimento, que insufla vida e energia cênica ao canônico texto grego, lançará outras luzes à construção discursiva desses poetas, uma vez que o texto de caráter oral, composto para uma apresentação pública específica, comunica elementos outros, que muitas vezes ficam obscurecidos na individual e silenciosa leitura do texto. Kathrin Rosenfield defende a importância da percepção corporal à interpretação da arte trágica de Sófocles. Refletindo sobre o obscurecimento do texto e a clareza do movimento corporal e da potência vocal do coro, escreve:

A tragédia clássica enfatiza esta complexidade pelo duplo registro da expressão, que opõe o discurso argumentativo dos diálogos aos cantos dançados! - do coro. As palavras destes cantos não são menos significativas e não lhes falta complexidade, muito pelo contrário. No entanto, toda essa riqueza semântica é deliberadamente obscurecida como no sfumato de uma pintura. Ela deve atingir o público de outro modo que o "compreensivo", entrando não pelo entendimento, mas pela sensibilidade do corpo e despertando possíveis pensamentos apenas num efeito retard. O que o público precisa sentir (mais que compreender), por exemplo, no penúltimo canto coral de Édipo, não é a genealogia tebana, nem o fato de que Édipo poderia ser filho de um deus, como Dionísio, que foi gerado pela união de Zeus com a tebana Sêmele. Ao contrário, o espectador precisa apenas sentir o poder da ilusão que o canto transmite no ponto mais alto da ação trágica: neste ponto já é mais que evidente que algo terrível aconteceu com Édipo, Laio e Jocasta; mas os anciãos ainda se refugiam na esperança de que haja uma solução maravilhosa para todo o imbroglio, e o espectador terá de ser seduzido corporal e sensualmente para sentir isto também. Apenas para sentir ainda mais o amargor do desfecho iminente. (2013, p. 21) 
Para Rosenfield, recuperando a ênfase dada por Nietzsche à presença corporal e a execução musical, é a compreensão desses elementos cênicos audíveis e visualizáveis - que poderia aprofundar nossa leitura e interpretação da tragédia. Em vista desta perspectiva, descreveremos não apenas o espaço de execução da tragédia, bem como a indumentária que tal encenação exigia. A partir deste detalhamento, poderemos rever a própria leitura do drama trágico a partir da presentificação do corpo do ator, da música e do canto do coro, da imagem do teatro, da cena e da peça sendo executada.

O espaço ritual das dionisíacas ocorria em um teatro que ficava entre a encosta da acrópole e o pequeno tempo em homenagem a Dioniso Eleuterios, de origem beócia, que ficava no sopé da formação rochosa (Grimal, 1986, p. 16). Como no alto da acrópole estavam os templos em homenagem aos olímpicos, uma vez ao ano, no decorrer dos cinco ou seis dias que constituíam a Dionisíaca, a pólis simbolicamente dava às costas aos deuses tradicionais para celebrar o onírico deus do vinho, fenômeno exemplificado pela própria localização geográfica do Teatro e do Templo de Dionísio, na encosta da Acrópole, ao lado do Parthenon (Beacham, 2007, p. 206) (Fig. 1).

Este teatro era composto de três partes (Fig. 2). A skiné ou cena originalmente uma simples "tenda", na qual os atores trocavam de máscaras entre os episódios. Esta daria origem ao moderno palco elevado (Malhadas, 2003 , p. 88). No caso do teatro grego, a passagem de uma simples tenda para uma skenai de madeira no século $\mathrm{V}$ e desta para uma construção mais elaborada e de pedra nos séculos posteriores exemplificam a gradativa importância que o herói ganha em relação ao coro (Fig. 3 e 2). Se no início não havia distinção entre eles, estando a gênese do ator justamente em função do coro, a introdução e a evolução da skenai corta o círculo da orquestra, redirecionando o olhar da platéia (Beacham, 2007, p. 205).

No choros ou orquestra, na etimologia grega o "lugar onde se dança", se apresentava o grupo de bailarinos que dançava e cantava nos estásimos e que dialogava individual - no caso do corifeu - ou coletivamente os atores nos episódios. E por fim, o próprio theatron (do verbo théan, ver) ou auditório, lugar de onde se vê (Grimal, 1986, p. 15-18). No decorrer do século V - ou seja, no decorrer da produção dos três grandes tragediógrafos - passa-se a pintar a fachada da skenai, dando origem ao cenário teatral. Todavia, não se trata ainda de teatro realista, mas de uma apresentação formal e ritualística que levava a audiência a refletir sobre religião, política, mito e outros temas humanos. Era este complexo suporte que Ésquilo, Sófocles e Eurípides tinham ao seu dispor em sua criação dramática (Beacham, 2007, p. 206).

Além desses elementos, a forma cônica do teatro, primeiro de maneira e depois de pedra, exemplificava a artesania arquitetônica e acústica que garantia que um público de dez a quinze mil pessoas pudesse assistir $e$ escutar aos que era encenado (McCart, 2007, p. 250). Sobre a imagem cênica, 
Lesky detalha as diferenças entre a visão moderna de teatro e a utilização do espaço cênico pelos gregos, afirmando que no caso destes o cenário

era simples, a orquestra ainda não apresenta fundo fixo, mas uma construção
de altura mediana que, neste caso, representava o altar da comunidade dos
deuses e era provido de estátuas ou símbolos. Que o coro se movia por essa
construção, no-lo sugerem certas passagens, que têm o sentido de direção
cênica e dirigem as jovens para o altar ou dele para a orquestra. (2010, p. 115)

Quanto ao coro, sua participação era maior, sendo indissociável da própria gênese da tragédia e da comédia grega. Em Ésquilo, suas falas correspondiam a mais de um terço da peça, sendo pouco a pouco diminuída nas peças de Sófocles e Eurípides (Finley, 1988, p. 91). Se no princípio, o coro era personagem dramática, participante da ação, nos autores posteriores ele vai se separando dos episódios. Assim, o canto coral passaria a reproduzir as impressões, apreensões e advertências comuns à audiência, sendo interpretado por diversos autores como uma extensão desta (Griffith, 2007, p. 23).

O coro costumava executar coreografias de dança, enquanto cantava em homenagem a Dionísio (Fig. 4). A música era o Ditirambo, música entoada no ritual dionisíaco com o acompanhamento da flauta dupla Aulos. Outros instrumentos, como a lira ou a cítara eram usadas como acompanhamento. Quanto às danças, podiam ser de dois tipos: emelia, dança gestual e compassada, de ritmo mais lento e serimonial; e hiporquema, mais rápida e intensa (Thiercy, 2009, p. 14). Era um espetáculo variado e multiforme, no qual diversas artes - visuais, corporias, musicais e literarias - se coadunavam a fim de produzir uma obra de arte complexa e sensorialmente estimulante.

$\mathrm{Na}$ própria estrutura das dionisíacas, os festivais dramáticos reuniam a polis tanto na formação do público quanto na própria feitura do espetáculo. Sabemos, por exemplo, que a participação nos coros era decidida com meses de antecedência, podendo qualquer cidadão participar das montagens trágicas e cômicas (Rehm, 2007, p. 187). A presença da orquestra, base da construção cênica, precede a criação da Skné. Ou seja, inicialmente era um espetáculo centrado na presença do coro, que dança e canta diante da platéia, supondo-se que inicialmente, o teatro constituía-se somente de platéia e orquestra (Fig. 3).

Se no decorrer do século $\mathrm{V}$ a.C., testemunha-se a gradativa diminuição da importância do coro, inversamente há a crescente importância das personagens. Uma das razões disso é a adição de mais atores. Aristóteles, na quarta seção da Poética, afirma que Ésquilo, além de um Protagonista, foi o primeiro a acrescentar o segundo ator ou Deuteragonista, o que leva a crer que em momento anterior, a tragédia correspondia a um diálogo apenas entre esta e o coro. Para alguns estudiosos, o próprio autor no princípio do teatro grego interpretava o herói único em diálogo com o coro (Griffith, 2007, p. 22). 
Sobre o aumento de número de atores, a Poética informa que Sófocles e Eurípides foram centrais a esse processo, fazendo com que o coro não mais participasse da ação, sendo a tragédia dramatizada por dois personagens. Grimal, por exemplo, interpreta a criação da skiné como uma forma de visual e tecnicamente separar o coro dos atores, destacando a individualidade deste da coletividade daquele (1986, p. 20). Essa progressão é perceptível na própria construção do texto trágico. Quando analisamos os textos dos três tragediógrafos percebemos essa gradativa alteração e sutil alteração.

Agamêmnon, de Ésquilo, por exemplo, necessitava, além do coro, de apenas dois atores (Tabela 1). Édipo Rei, de Sófocles, por sua vez, de três (Tabela 2). Medeia, de Eurípides, precisaria, em algumas cenas de mais de três atores, se levarmos em conta a presença da ama em algumas cenas. Entretanto, por mais profícua que tal gradação possa parecer, nem sempre ela é perfeita. Eumênides, por exemplo, dificilmente foi apresentada com menos de três atores, o que colocaria o próprio Ésquilo como autor dessa inovação (Tabela 3).

Entretanto, não era apenas no que concerne à participação do drama e aos objetivos cênicos que os atores e os componentes do coro se diferenciavam. Havia também uma diferença dialetal que afastava a linguagem do coro, mais ritual, sonora e artificial, da linguagem ática dos episódios dialogados, mais próxima da fala cotidiana. Segundo Lesky essa diferente "matriz dialetal" ressignificaria a compreensão do ator e do coro.

Este, no dialeto dórico da lírica coral, aquele no iambo ático, que em alguns
detalhes revela uma coloração jônica. Ambos são também portadores de
diferentes formas de expressão humana. No canto coral está representado o
que é da ordem dos sentimentos, enquanto que as falas do ator servem ao
desenvolvimento temático. A união de dois elementos, já indicada, - o
dionisíaco-ditirâmbico e a Logos apolínea - surge aqui sob nova perspectiva.
(2010, p. 85)

Assim, se no início a diferenciação entre coro e atores inexistia, o que vemos no desenvolvimento do drama ateniense do século $\mathrm{V}$ é o afastamento linguístico e estrutural - entre a forma dialogada dos heróis e as execuções musicais do coro. Em geral, nas peças dos dramaturgos posteriores, como Sófocles e Eurípides, o coro passa a ser menos importante à ação e ao enredo do que era em Ésquilo. Deste, a Oréstia ainda é o grande exemplo da importância dramática do coro de anciãos, de coéforas e de fúrias, em cada peça da trilogia. Nas Suplicantes, peça um pouco anterior, o próprio coro é o protagonista da peça, que trata da fuga das cinquenta filhas de Danaus.

Por fim, as máscaras também marcavam essa diferença. O coro, ao que tudo indica, não as usava, sendo sua coletividade uma simbólica máscara social daquilo que representava - anciãos, amas, escravas, bacantes, entre outras. Diferentemente, era justamente ela que caracterizava o sexo, a idade e também a posição social - monárquica, religiosa ou servil - das personagens. 
Tendo sua origem nos próprios rituais dionisíacos, a máscara simbolizava não apenas um disfarce cênico, como a própria possessão do autor pelo ser mortal ou imortal - que interpretava (Easterling, 1997, p. 49).

Há várias funções figuradas na sua utilização por parte do herói. Além de diferenciar heróis trágicos (Fig. 7 e 8) de personagens cômicas (Fig. 9 e 10), ela possuía uma clara função ritual e religiosa. Ademais, se instaura como fundamental ferramenta cênica facilitadora, uma vez que um ator pode interpretar dois, três ou mais personagens (ibidem, p. 51). Em Édipo Rei, por exemplo, o segundo ator interpretava vários papeis: Sacerdote, Tirésias, Jocasta, Pastor e Servo. Em As Bacantes, de Eurípides, possivelmente o ator que interpretava Penteu interpretava também a sua mãe Agave. Em todas as tragédias, encontramos um grande número de personagens que não dividem a cena, o que nos faz cogitar sobre quantos e quais atores interpretavam cada papel. Além disso, autores como McCart supõem que a máscara, com a abertura da boca em formato de cone unida ao efeito acústico produzido pela construção arquitetônica do teatro, ampliavam a voz do ator (2007, p. 249).

Por outro lado, se a máscara funcionava como um recurso visual e sonoro importante, o mesmo não pode ser dito sobre os outros adereços. Ao que tudo indica, as vestimentas eram simples, sem haver identificação entre roupas de reis ou servos, de personagens masculinos ou femininos, embora possamos cogitar pequenos objetos de caráter simbólico, como o arco de Apolo, o cetro de um rei, as armas de um guerreiro, o cajado de um homem velho ou de um profeta cego (Malhadas, 2003, p. 89) (Fig. 6). As Bacantes, por exemplo, na forma como Penteu detalha a indumentária e os traços físicos de Dionísio, nos fazem refletir sobre até que ponto essa aparente simplicidade era de fato uma realidade no drama ateniense.

$\mathrm{Na}$ quarta parte da Poética, Aristóteles menciona que Sófocles foi responsável por outra inovação ao acrescentar o cenário. Não sabemos exatamente o que o filósofo compreende por cenário - se uma skiné mais elaborada ou se painéis figurativos, como alguns autores supõe. Todavia, essa informação também nos faz atentar a determinados mecanismos utilizados na apresentação cênica par produzir determinados efeitos, entre eles exteriorizar crimes ocorridos dentro do palácio - da skiné - e introduzir personagens divinas ou fugas extraordinárias, como no final da Medeia de Eurípides.

O primeiro desses dispositivos era a ekkylkléma, dispositivo que abria as portas da skiné de pedra para revelar à audiência crimes ocorridos no interior do palácio cênico. Além dessa abertura, um pequeno palco móvel saia do interior da skenai, revelando corpos feridos ou mortos (Grimal, 1986, p. 22) (Fig. 5). Devemos imaginar a utilização desse dispositivo no fim de Agamêmnon, quando o corpo do rei de Argos e de Cassandra são revelados à audiência.

O segundo - coincidentemente chamado de máquina ou mechané que viabilizava dramas nos quais figuras divinas ou heróicas surgiam em cena. 
Tratava-se de um antigo guindaste de madeira, possivelmente com roldanas, que içava um ator para fora do palco (Fig. 5). Conhecido como recurso Deus ex machina, era o responsável pela resolução de peças com auxílio divino. Grimal, baseando-se no teatro de Erétria, supõe que também criaturas infernais surgiam em cena, porém de um compartimento subterrâneo, "as escadas do Caronte", de onde deuses infernais e Fúrias vingativas surgiam (Ibidem, p. 23).

Todos esses recursos técnicos - o teatro e sua acústica, a máscara dramática, o cuidado com a progressão do coro e sua relação sempre dinâmica com as personagens, e os efeitos cênicas propiciados pela ekekykléma e pela mechané - revelam o alto nível da artesania dramática grega. Preparando-se com meses de antecedência para um espetáculo de apresentação única, todos os envolvidos assumiam seus papeis com o máximo de atenção. Essa recuperação do entorno histórico, bem como a incrível complexidade do texto trágico e cômico, revelam esse comprometimento.

\section{O corpo, a voz, o texto: da tragédia como espetáculo cênico}

Autores como Bruno Snell diferenciam a poesia da tragédia no que tange à referência e à execução da dança. A poesia, desde Homero, e em especial na lírica coral pode apresentar remissões de gestos e passos de dança. Lembrem-nos da descrição do escudo de Aquiles no canto 18 da Ilíada que inicia e finda com um festejo no qual a dança tem papel fundamental ou mesmo da descrição do aedo Demódoco, no Canto 8 da Odisseia. Também Baquílides de Ceos - poeta do século VI, sobrinho de Simônides e adversário poético de Píndaro - cantou, o mito de Teseu, descrevendo uma dança coral em homenagem a Apolo quando o herói chega em Delos.

Nesse sentido, para Snell, o que caracteriza o teatro não é, como na poesia, uma descrição ou uma remissão à dança, mas a própria dança como central à execução dramática. Sobre a relação entre tragédia e poesia lírica, Snell afirma que a

\footnotetext{
tragédia compunha-se, na origem, de dança e canto coral em honra a Dioniso, que os cantores executavam usando máscaras animalescas e assim assumindo uma forma primitiva do Divino: desse modo, mundo mítico e realidade terrena tornavam-se uma só coisa enquanto durasse a dança. A lírica coral e o drama têm, portanto, origens muito afins, mas diferenciam-se essencialmente pelo modo como ascenderam às grandes formas literárias, vale dizer, pelo modo como acolheram os mitos da poesia épica. (2009, p. 99)
}

Neste aspecto, nos interessa a ênfase dado pelo autor à significância que o corpo e a dança ganham no espetáculo cênico. Nas origens da lírica coral e do drama, temos a dança sacra, pela qual o mundo dos deuses se identifica com a realidade terrena do presente. Aqui, "realidade" tem um sentido distinto da realidade da narração épica: não se trata de um fato verdadeiro ou falso, 
acontecido outrora, que pode ser "narrado"; antes, de um acontecimento mítico "revivido" na ação dramática. Para atores e público essa representação "é" o acontecimento mítico e, todavia, em certo sentido, não o é, na medida em que se sabe que o herói é "representado" por um ator (ibidem, p. 103).

Embora Snell esteja interessado mais no modo como lírica e tragédia apresentam a relação entre mito e realidade, essa diferenciação é importante por evidenciar como interessava aos tragediógrafos não apenas a letra cantada e a música - como no caso da lírica -, mas também a dimensão corporal e visual representada inicialmente pelo coro e posteriormente pelo intercâmbio cênico entre o coro e os atores/personagens. Em outros termos, para o drama dionisíaco, o corpo e o discurso tinham papel central, sendo justamente da dinâmica entre eles que se estabelecia o espetáculo trágico.

A tragédia é uma forma de arte que une o mais civilizado e o mais primitivo; as formas discursivas e as reflexões jurídicas, filosóficas e mesmo religiosas presentes no diálogo são entrecortadas pela música e pela dança dos estásimos corais. Aqui, não se trata de reavivar a oposição nietzschiana entre o apolíneo da linguagem e da razão em oposição ao dionisíaco dos instintos ctônicos primitivos, evidenciados pela música e pela dança. Antes, trata-se de perceber no jogo teatral ateniense, representado no teatro de Dionísio a completa penetração das paixões, das forças naturais/divinas e dos instintos humanos na ceara da ordem urbana, do pensamento lógico, da estruturação jurídica e política. Como sabemos, Ésquilo, Sófocles e Eurípides são mais reconhecíveis pelos modos diversos em que aturaram sob o gênero trágico; todavia, seus Xerxes, Édipo e Penteu são todos levados, nas suas respectivas desmedidas, por forças naturais/divinas/instintivas que não compreendem e que, às vezes, até desprezam. Em outros termos, apesar de suas diferenças, é o elemento musical/corporal o traço comum entre os três dramaturgos.

No teatro, a destruição das certezas humanas estáticas ganha o traçado visual do movimento cênico, dos passos extáticos do coro. Enquanto o homem dialoga no drama, o coro que homenageia o deus da mudança, Dionísio, encena a própria mudança circular da natureza. É toda essa dimensão cênica da tragédia no seu contexto e na arquitetura circular do teatro grego que perdemos ao acessar a tragédia unicamente em sua forma textual.

É comum a diferenciação entre a tragédia grega para a moderna calcada no conflito com o divino e com o próprio humano. Mas não se trata apenas disso, de afirmar meramente que Édipo luta com os deuses ou com o mundo natural incontrolável e que Hamlet, diferentemente, batalha contra si próprio ou com outro(s) ser(es) humano(s). Tal diferenciação é apenas textual, sendo que ambos figuram um processo de encenação totalmente diverso. A tragédia ateniense, ao unir música e dança, não como acessória, mas como elemento central e primordial da representação, traz ao jogo cênico outra 
dimensão ao drama. É essa dimensão que tentamos reconstituir nesse texto e que doravante discutiremos em nossos estudos do texto trágico.

Recebido em 14 de Julho de 2013. Aceito em 03 de Outubro de 2013.

\section{REFERÊNCIAS}

BEACHEM, Richard. "Playing places: the temporary and the permanent". In: MCDONALD, Marianne. WALTON, Michael J. (Ed) The Cambridge Companion to Greek and Roman Theatre. Cambridge: Cambridge University Press, 2007, p. 202-226.

BURIAN, Peter. "Myth into muthos: the shaping of tragic plot". In: EASTERLING, P. E. (ed.) The Cambridge Companion to Greek Tragedy. Cambridge: Cambridge University Press, 1997, p. 178-208.

DETIENNE, Marcel. Dioniso a céu aberto. Rio de Janeiro: Jorge Zahar Editor, 1988.

EASTERLING, P. E. “A show for Dionysus". In: EASTERLING, P. E. (ed.) The Cambridge Companion to Greek Tragedy. Cambridge: Cambridge University Press, 1997, p. 36-53.

FINLEY, M. I. Os Gregos Antigos. Lisboa: Edições 70, 1988.

GASSNER, John. Mestres do Teatro I. São Paulo: Perspectiva, 2007.

GRAF, Fritz. "Religion and drama." In: MCDONALD, Marianne. WALTON, Michael J. (Ed) The Cambridge Companion to Greek and Roman Theatre. Cambridge: Cambridge University Press, 2007, p. 55-71.

GRIFFITH, Mark. "'Telling the tale': a performing tradition from Homer to pantomime." In: In: MCDONALD, Marianne. WALTON, Michael J. (Ed) The Cambridge Companion to Greek and Roman Theatre. Cambridge: Cambridge University Press, 2007, p. 13-35.

GRIMAL, Pierre. O teatro antigo. Lisboa: Edições 70, 1986.

HESK, Jon. "The socio-political dimension of ancient tragedy". In: MCDONALD, Marianne. WALTON, Michael J. (Ed) The Cambridge Companion to Greek and Roman Theatre. Cambridge: Cambridge University Press, 2007, p. 72-91.

In: MCDONALD, Marianne. WALTON, Michael J. (Ed) The Cambridge Companion to Greek and Roman Theatre. Cambridge: Cambridge University Press, 2007.

JAEGER, Werner. Paidéia A Formação do Homem Grego. São Paulo: Martins Fontes, 2001.

KNOX, Bernard. Édipo em Tebas. São Paulo: Perspectiva, 2003. LESKY, Albin. A tragédia grega. São Paulo: Perspectiva, 2010. 
MACCART, Gregory. "Masks in Greek and Roman theatre." In: MCDONALD, Marianne. WALTON, Michael J. (Ed) The Cambridge Companion to Greek and Roman Theatre. Cambridge: Cambridge University Press, 2007, p. 247-267.

MALHADAS, Daisi. Tragédia Grega - O Mito em Cena. São Paulo: Ateliê Editorial, 2003.

NIETZSCHE, Friedrich. "O Drama Musical Grego". In: Nietzsche, Friedrich. A Visão Dionisíaca do Mundo. São Paulo: Martins Fontes, 2005.

NIETZSCHE, Friedrich. A Visão Dionisíaca do Mundo. São Paulo: Martins Fontes, 2005.

OST, François. Contar a Lei - As fontes do imaginário jurídico. São Leopoldo: Unisinos, 2004.

ROMILLY, Jacqueline. A tragédia grega. Trad. Ivo Martinazzo. Brasília: Universidade Federal de Brasília, 1998, p. 150.

SNELL, Bruno. "Mito e Realidade na Tragédia Grega". In: SNELL, Bruno. A Cultura Grega e as Origens do Pensamento Europeu. São Paulo: Perspectiva, 2009, p. 97-116.

THIERCY, Pascal. Tragédia Grega. Porto Alegre: L\&PM, 2009. 
Tabelas

Tabela 1 - Encenação Original de Agamêmnon, de Ésquilo

\begin{tabular}{|c|c|c|c|c||c|c|c|c||c|c|c|}
\hline & Prólogo & Par. & $\begin{array}{c}\text { Epis. } \\
\mathbf{1}\end{array}$ & $\begin{array}{c}\text { Est. } \\
\mathbf{1}\end{array}$ & $\begin{array}{c}\text { Epis. } \\
\mathbf{2} .\end{array}$ & $\begin{array}{c}\text { Est. } \\
\mathbf{2}\end{array}$ & $\begin{array}{c}\text { Epis. } \\
\mathbf{3}\end{array}$ & $\begin{array}{c}\text { Est. } \\
\mathbf{3}\end{array}$ & $\begin{array}{c}\text { Epis. } \\
\mathbf{4}\end{array}$ & $\begin{array}{c}\text { Estás. } \\
\mathbf{4}\end{array}$ & Exodo \\
\hline $\begin{array}{c}\text { Ator } \\
\mathbf{1}\end{array}$ & & & Clitem. & & Clitem. & & Clitem. & & Clitem. & & Clitem. \\
\hline $\begin{array}{c}\text { Ator } \\
\mathbf{2}\end{array}$ & & & & & & & & & & & \\
\hline Continela & & Ancião & & Arauto & & Agam. & & Cassa. & & Egisto \\
\hline
\end{tabular}

Tabela 2 - Encenação Original de Édipo Rei, de Sófocles

\begin{tabular}{|c|c|c||c|c|c|c|c|c|c|}
\hline & Prólogo & Párodo & Epis. & Estás. & Epis. & Estás.2 & Epis. & Estás. \\
$\mathbf{1}$ & & $\mathbf{1}$ & $\mathbf{2}$ & & $\mathbf{E}$ & $\mathbf{3}$ & \\
\hline Ator 1 & Édipo & & Édipo & & Édipo & & Edipo & & Edipo \\
\hline Ator 2 & Sacerdote & & Tirésias & & Jocasta & & $\begin{array}{c}\text { Jocasta/ } \\
\text { Pastor }\end{array}$ & & Servo \\
\hline Ator 3 & Creonte & & & & Creonte & & Mensageiro & & Creonte \\
\hline Coro & Suplicantes & Coro & Corifeu & Coro & Corifeu & Coro & Corifeu & Coro & Corifeu \\
\hline
\end{tabular}

Tabela 3 - Encenação Original de As Eumênides, de Ésquilo

\begin{tabular}{|c|c|c||c||c|c|c|c||c|}
\hline & Prólogo & Párodo & $\begin{array}{c}\text { Epis. } \\
\mathbf{1}\end{array}$ & $\begin{array}{c}\text { Estás. } \\
\mathbf{1}\end{array}$ & $\begin{array}{c}\text { Epis. } \\
\mathbf{2 .}\end{array}$ & Estás.2 & Epis.3 & $\begin{array}{c}\text { Estás. 3 } \\
\text { Exodo }\end{array}$ \\
\hline Ator 1 & Orestes & & Orestes & & Orestes & & Orestes & \\
\hline Ator 2 & $\begin{array}{c}\text { Apolo, } \\
\text { Clitemenestra }\end{array}$ & & Apolo & & & & Apolo & \\
\hline Ator 3 & $\begin{array}{c}\text { Profetiza, } \\
\text { Hermes }\end{array}$ & & & & Atenas & & Atena & Atena \\
\hline Coro & Fúrias & Coro & Corifeu & Coro & Corifeu & Coro & Corifeu & Coro \\
\hline
\end{tabular}

